\title{
Genome-Wide Analysis of Histone H3 Lysine 4 Trimethylation in Peripheral Blood Mononuclear Cells of Minimal Change Nephrotic Syndrome Patients
}

\author{
Li Zhang $^{\text {a }}$ Yong Dai ${ }^{a} \quad$ Wujian Peng ${ }^{a} \quad$ Juanjuan Lu ${ }^{b} \quad$ Yanliang Zhang ${ }^{a}$ \\ Linxian Wang ${ }^{\text {a }}$ \\ aSecond Clinical Medical College, Jinan University, Guangzhou, and ${ }^{\text {b}}$ First Affiliated Hospital, Shantou University \\ Medical College, Shantou, China
}

\section{Key Words}

Minimal change nephrotic syndrome $\cdot$ Histone $\mathrm{H} 3$ lysine $4 \cdot$ Trimethylation • Chromatin immunoprecipitation • Microarray

\begin{abstract}
Background:Studies of the epigenome have attracted some interest in nephrology. However, to date, our knowledge about the alterations in histone modification in minimal change nephrotic syndrome (MCNS) is unknown. This study aimed to investigate the variations in histone $\mathrm{H} 3$ lysine 4 trimethylation (H3K4me3) in peripheral blood mononuclear cells of patients with MCNS. Methods: H3K4me3 variations were analyzed in peripheral blood mononuclear cells, from 15 MCNS patients and 15 healthy subjects, using the ChIPchip approach. ChIP real-time PCR is used to validate the microarray results. In addition, mRNA expression and DNA methylation status can also be further analyzed by quantitative (q) RT-PCR and methyl-DNA immunoprecipitation-q PCR, respectively. Results: 848 increased and 231 decreased $\mathrm{H} 3 \mathrm{~K} 4 \mathrm{me} 3$ probes displaying significant $\mathrm{H} 3 \mathrm{~K} 4 \mathrm{me} 3$ differences were found in MCNS patients compared with healthy subjects. The results of ChIP real-time PCR coincided well with
\end{abstract}

the microarray. Expression analysis by qRT-PCR revealed positive correlations between mRNA and H3K4me3 levels. DNA methylation alterations were found on selected positive genes (IL4R, HIVEP3, HPSE2, CDH13 and PRKD2). In addition, we also found that there is an inverse relationship between $\mathrm{H} 3 \mathrm{~K} 4 \mathrm{me} 3$ and promoter DNA methylation in MCNS patients. Conclusion: Our studies indicate that there are significant alterations of $\mathrm{H} 3 \mathrm{~K} 4 \mathrm{me} 3$ in MCNS patients. These significant $\mathrm{H} 3 \mathrm{~K} 4 \mathrm{me} 3$ candidates may help to explain the immunological disturbance involved in MCNS patients.

Copyright $\odot 2009$ S. Karger AG, Basel

\section{Introduction}

Minimal change nephrotic syndrome (MCNS) is a common glomerular kidney disease in childhood, present in approximately $77 \%$ of the large sample of children in the International Study of Kidney Disease in Children [1]. Conversely, among adults, only $20-30 \%$ of patients with nephrotic syndrome show this abnormality $[2,3]$. MCNS usually responds well to corticosteroid therapy and is considered to be an immunologically mediated disease $[4,5]$. Both depressed and enhanced cell-medi-

\section{KARGER}

Fax +41613061234 E-Mail karger@karger.ch www.karger.com (c) 2009 S. Karger AG, Basel

0250-8095/09/0306-0505\$26.00/0

Accessible online at:

www.karger.com/ajn
Yong Dai, $\mathrm{PhD}$

Shenzhen People's Hospital

1017 North Road, Dongmen

Shenzhen 518020, Guangdong (China)

Tel. +86 1380220 1510, Fax +86 7552562 6750, E-Mail daiyong22@yahoo.com.cn 
ated immunity has been observed during relapses. Experimental studies have shown that peripheral blood mononuclear cells (PBMCs) and T cell hybridomas made from patients with MCNS released proteinuria-inducing factors in rats [6-8]. Various cytokines released by PBMCs from MCNS patients have also been demonstrated in vivo and in vitro [9-11]. It has been suggested that these soluble mediators disrupt the glomerular filter, resulting in proteinuria. However, to date, the mechanism of immunological disturbance in MCNS patients is still unknown. Therefore, it is necessary to study the pathogenesis of MCNS further.

Histone lysine methylation, which is one of the important epigenetic modifications, is believed to be part of a histone code and has been implicated in multiple biological processes including gene activation, silencing, $\mathrm{X}$-chromosome inactivation, DNA repair, cell cycle control and DNA methylation [12-14]. Lysines can accept 3 methyl groups and can therefore be monomethylated, dimethylated or trimethylated. Recent evidence suggests that there may be functional differences among these methylation states. Among the various histone lysine methylation patterns, much attention has recently been focused on methylation at lysine 4 of histone $\mathrm{H} 3$ (H3K4), owing to its association with active chromatin and gene expression [15-17]. Trimethylated H3K4 (H3K4me3) is preferentially detected at active genes and is proposed to promote gene expression through recognition by transcription-activating effector molecules [18]. Aberrant alterations in histone lysine methylation patterns that change chromatin structure could lead to dysregulated gene transcription and disease progression $[13,19]$. Therefore, it is of significant interest to investigate whether there are aberrant $\mathrm{H} 3 \mathrm{~K} 4 \mathrm{me} 3$ in PBMCs from MCNS patients. This may provide important clues to assist in the development of new treatments for MCNS as well as give us a deeper understanding of the etiology of MCNS.

Recent advances in technology have made it possible to analyze chromatin structure at the genome level in mammalian cells. Genome-wide information on histone modifications can be observed using a technique called chromatin immunoprecipitation linked to microarrays (ChIP-chip), which is unbiased and has high-throughput capability. This new high-throughput strategy has been widely used in epigenetic studies [20-23]. Ren et al. [24] first identified novel targets of the yeast transcription factors Gal4 and Ste12 with ChIP-chip on a yeast intergenic DNA array. Meanwhile, in humans, one of the first ChIPchip experiments adopted was the use of a CpG island array for screening novel E2F4 targets [25]. Recently, this
Table 1. Characteristics of MCNS patients and healthy controls

\begin{tabular}{lcl}
\hline Characteristics & $\begin{array}{l}\text { MCNS patients } \\
(\mathrm{n}=15)\end{array}$ & $\begin{array}{l}\text { Healthy subjects } \\
(\mathrm{n}=15)\end{array}$ \\
\hline Males/females & $10 / 5$ & $10 / 5$ \\
Age, years & $41.73 \pm 6.12$ & $39.06 \pm 6.50$ \\
Plasma albumin, g/l & $21.20 \pm 4.81$ & $43.75 \pm 14.38$ \\
Proteinuria, g/day & $4.45 \pm 1.78$ & negative \\
Serum creatinine, mg/dl & $0.93 \pm 0.26$ & $0.96 . \pm 0.23$ \\
Serum cholesterol, mM & $7.38 \pm 2.35$ & $3.12 \pm 1.19$ \\
\hline
\end{tabular}

Values are expressed as means $\pm \mathrm{SD}$.

approach has been applied successfully to delineate the profile of $\mathrm{H} 3 \mathrm{~K} 9$ and $\mathrm{H} 3 \mathrm{~K} 27$ methylation in human disease [26-28].

At present, studies of the epigenome have attracted some interest in nephrology. However, to date, there are no reports of MCNS research from the aspect of histone modification. Hence, in this study, we adopted ChIP-chip technology to profile and compare the variations in $\mathrm{H} 3 \mathrm{~K} 4 \mathrm{me} 3$ at a genome-wide level of PBMCs from MCNS patients and healthy controls to gain a better understanding of the pathogenic mechanisms in MCNS. Meanwhile, we also explored the relevance of H3K4me3 and DNA methylation under this disease condition.

\section{Materials and Methods}

Human Subjects

Fifteen adults with MCNS were enrolled in the study. All the patients had undergone a renal biopsy for an exact histological diagnosis. Diagnostic criteria for nephrotic syndrome were massive proteinuria ( $>3.5 \mathrm{~g} /$ day) and hypoalbuminemia $(<3 \mathrm{~g} / 100$ $\mathrm{ml}$ ) with or without edema. These patients were recruited from the inpatient section in the kidney transplantation and hemopurification center of Guilin's 181 Hospital, Guilin. None of these patients were treated with any medications that might have affected our interpretation of the data. Age-, race- and sex-matched healthy controls were recruited through advertising. The clinical features of the patients and healthy subjects are shown in table 1. PBMCs were isolated from heparinized venous blood (10 $\mathrm{ml}$ per subject) within $1 \mathrm{~h}$ after hemostasia according to the Ficoll-Paque Plus instructions. The ethics committee of the Jinan University approved the study and peripheral blood samples were obtained with the informed consent of all participating individuals.

Isolation of PBMCs

Blood samples were obtained from MCNS patients $(n=15)$ and healthy donors $(\mathrm{n}=15)$. The blood $(10 \mathrm{ml}$ per subject $)$ was diluted with equal volumes of phosphate-buffered saline. An 
Table 2. ChIP-qPCR primers used for validation of the CpG array data

\begin{tabular}{llll}
\hline Gene & Primer sequence $\left(5^{\prime}\right.$ to $\left.3^{\prime}\right)$ & $\begin{array}{l}\text { Anneal- } \\
\text { ing, }{ }^{\circ} \mathrm{C}\end{array}$ & $\begin{array}{l}\text { Size } \\
\text { bp }\end{array}$ \\
\hline IL4R & $\begin{array}{l}\text { F: AGTTCTGTCTAAATGCGTCCGT } \\
\text { R: GAACTCAATTCCACCAAACCCT }\end{array}$ & 59 & 290 \\
\hline PRKD2 & $\begin{array}{l}\text { F: GAGCTGCGAAGGAAGAGGA } \\
\text { R: GAGGCTGAGGCACGAGAAT }\end{array}$ & 59 & 277 \\
\hline HPSE2 & $\begin{array}{l}\text { F: GGAAAGCATTAGGCGAACAGG } \\
\text { R: GCTCGTCCGAATGTAGGGTG }\end{array}$ & 59 & 143 \\
\hline CDH13 & $\begin{array}{l}\text { F: GACATTGCCGTCTGTTTCCT } \\
\text { R: CCACAGTGCCCTCCTGTTTAG }\end{array}$ & & \\
& & & \\
\hline
\end{tabular}

$\mathrm{F}=$ Forward primer $\mathrm{R}=$ reverse primer.

equal volume of diluted blood was overlaid on Ficoll-Paque Plus in a $1: 1$ ratio and centrifuged at $800 \mathrm{~g}$ for $25 \mathrm{~min}$ at $22^{\circ} \mathrm{C}$. The PBMC layer was harvested and washed twice with phosphatebuffered saline to remove plasma and Ficoll. These samples were then stored at $-80^{\circ} \mathrm{C}$ until assay.

\section{Chromatin Immunoprecipitation Microarray}

The ChIP-chip was performed according to described protocols [29] with some modifications. Briefly, PBMCs were crosslinked with $1 \%$ formaldehyde (final concentration) for $10 \mathrm{~min}$ at $37^{\circ} \mathrm{C}$; glycine $(0.125 \mathrm{M})$ was then added for $5 \mathrm{~min}$ at $37^{\circ} \mathrm{C}$ to stop the reaction. After being washed twice with $10 \mathrm{ml}$ of ice-cold $1 \times$ PBS, the cell pellets were resuspended with $300 \mu \mathrm{l}$ of lysis buffer (10 mM Tris-HCl, pH 8.0; NaCl 100 mM; EDTA 1 mM, pH 8.0; Nadeoxycholate $0.1 \%$; and protease inhibitors) and incubated on ice for $30 \mathrm{~min}$. Then, the cell suspension was sonicated for a total time of $4 \mathrm{~min}$ ( $30 \mathrm{~s}$ 'on' and $30 \mathrm{~s}$ 'off') to reduce DNA lengths to 200 $1,000 \mathrm{bp} .555 \mu \mathrm{l}$ of dilution buffer containing a protease inhibitor cocktail was added to each ChIP sample. The lysate was then divided into 3 fractions. The 1st lysate was incubated with anti-K4 trimethylated histone $\mathrm{H} 3$ antibody (Upstate Biotechnology, Lake Placid, N.Y., USA) at $4^{\circ} \mathrm{C}$ overnight. The 2 nd lysate was used as an input control and the 3 rd lysate was used as a negative control. To collect the immunoprecipitated complexes, $50 \mu \mathrm{l}$ of magnetic beads (Bangs Laboratories Inc.) were added and incubated for $1 \mathrm{~h}$ at $4^{\circ} \mathrm{C}$. Pellet beads were prepared by a magnetic separation rack for $2 \mathrm{~min}$ at $4^{\circ} \mathrm{C}$, with the magnetic beads sequentially washed in low salt $(0.1 \%$ SDS; $1 \%$ Triton X-100; 2 mM EDTA; 20 mM Tris$\mathrm{HCl}, \mathrm{pH} 8.1 ; 150 \mathrm{~mm} \mathrm{NaCl})$, high salt $(0.1 \%$ SDS; $1 \%$ Triton X-100; 2 mM EDTA; 20 mM Tris-HCl, pH 8.1; 500 mM NaCl), LiCl salt (0.25 M LiCl; 1\% NP40; 1\% deoxycholate; $1 \mathrm{~mm}$ EDTA; $10 \mathrm{~mm}$ Tris- $\mathrm{HCl}, \mathrm{pH}$ 8.1) and TE buffers (10 mM Tris-HCl; 1 mM EDTA, $\mathrm{pH}$ 8.0). The protein/DNA complexes were eluted and formaldehyde cross-links were reversed by heating the sample at $65^{\circ} \mathrm{C}$ for $5 \mathrm{~h}$. Samples were treated with RNase for $20 \mathrm{~min}$ at $37^{\circ} \mathrm{C}$ and then with proteinase K overnight. DNA was extracted by the phenol/ chloroform method, ethanol-precipitated and resuspended in water. PCR amplification of DNA was carried out with diluted DNA aliquots, according to the whole genome amplification kit (Sigma) instructions. After the amplification, DNA was purified by the
Table 3. Primers used in real-time qRT-PCR

\begin{tabular}{|c|c|c|c|}
\hline Gene & Primer sequence $\left(5^{\prime}\right.$ to $\left.3^{\prime}\right)$ & $\begin{array}{l}\text { Annealing } \\
{ }^{\circ} \mathrm{C}\end{array}$ & $\begin{array}{l}\text { Size } \\
\text { bp }\end{array}$ \\
\hline IL4R & $\begin{array}{l}\text { F: CAGCACCAAGTGGCACAAC } \\
\text { R: TGACATAGCACAACAGGCAGA }\end{array}$ & 59 & 110 \\
\hline HIVEP3 & $\begin{array}{l}\text { F: CAGTTTTGGTCATCGGAAGTG } \\
\text { R: GGATGTCAGTATTGCCATTG- } \\
\text { TATT }\end{array}$ & 59 & 264 \\
\hline PRKD2 & $\begin{array}{l}\text { F: CTTCCAGAACAACACGACCAA } \\
\text { R: GCATCTCGCCCACGAAGTA }\end{array}$ & 59 & 161 \\
\hline HPSE2 & $\begin{array}{l}\text { F: GCCTGCCGCTACCGATAA } \\
\text { R: TCCTTTGGGATGGATGTGG }\end{array}$ & 59 & 220 \\
\hline
\end{tabular}

$\mathrm{F}=$ Forward primer; $\mathrm{R}=$ reverse primer.
QIAquick PCR purification kit (Qiagen), Cy5 $5^{\mathrm{TM}}-\mathrm{dUTP}$ and Cy3 $3^{\mathrm{TM}}$-dUTP-labeled (Invitrogen) methylated $\mathrm{K} 4$ precipitated DNA and input DNA, and cohybridized to the human $12 \mathrm{~K} \mathrm{CpG}$ island array (UNH Microarray Centre, Toronto, Ont., Canada). The sequences of the $\mathrm{CpG}$ islands on the array and alignment data are available at http://data.microarrays.ca/.

The hybridized microarray slides were then scanned using a GenePix 4000B scanner (Axon Instruments, Foster City, Calif., USA). GenePix pro v6.0 was used to read the raw intensity of the image. The resulting text files were imported into Agilent GeneSpring GX software for further analysis. The 2 microarray data sets were normalized in GeneSpring GX using an Agilent 2-color scenario (mainly LOWESS normalization), and then CpGs marked present ('all target values') were chosen for further analysis. The differences between test and control samples were identified by 2 -fold change.

\section{Chromatin Immunoprecipitation-Quantitative Polymerase}

Chain Reaction

ChIP was conducted in the same way as ChIP-chip. The DNA pool from ChIP, input control and negative control was used for quantitative (q) PCR. PCR amplification was performed on an ABI 7700 real-time PCR (Applied Biosystems, Foster City, Calif., USA). The PCR conditions were an initial step of $4 \mathrm{~min}$ at $95^{\circ} \mathrm{C}$, followed by 40 cycles of $15 \mathrm{~s}$ at $95^{\circ} \mathrm{C}, 20 \mathrm{~s}$ at $59^{\circ} \mathrm{C}$ and $20 \mathrm{~s}$ at $72^{\circ} \mathrm{C}$. Primers were designed according to the selected genes for evaluating ChIP on chip data (table 2). To generate a standard curve for each amplicon, threshold cycle (CT) values of serially diluted input DNA, which were extracted in the ChIP experiment, were determined. The H3K4me3 changes were determined using the $2^{-\Delta \Delta C T}$ method [30]. A melting curve analysis was performed for each reaction to ensure a single peak. Each experiment was performed in triplicate, with the values averaged to obtain 1 datum per sample.

\section{RNA Extraction and Real-Time qRT-PCR}

Total RNA was extracted from PBMCs with Trizol reagent (Invitrogen) according to the manufacturer's instructions. The concentration and quality of RNA were measured by UV absorbance at 260 and $280 \mathrm{~nm}$ (A260/A280 ratio) and checked by agarose gel 


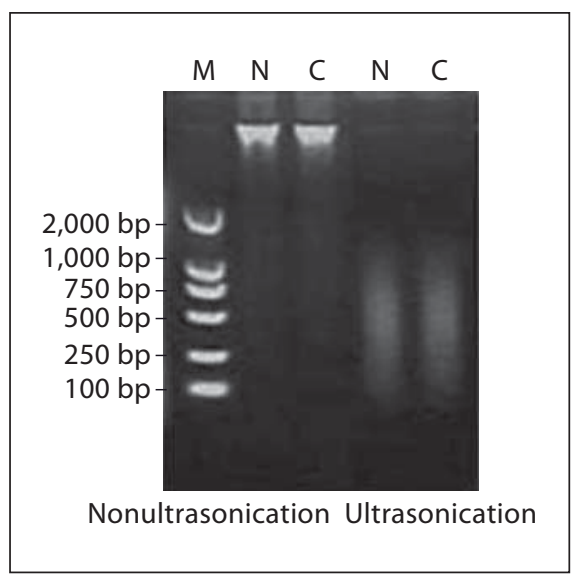

Fig. 1. DNA electrophoretogram. Sonicated effects were judged by the agarose gel electrophoresis. After ultrasonication, the genomic DNA fragments were approximately 1,000 bp. $\mathrm{M}=$ DL2000 marker; $\mathrm{N}=$ MCNS patients; $\mathrm{C}=$ healthy control group.

electrophoresis individually. Two micrograms of total RNA was reverse transcribed into cDNA with M-MLV reverse transcriptase and oligo-dT was used as a primer. Real-time PCR involved SYBR green dye and Taq polymerase. One-tenth of the resulting cDNA template was used for DNA amplification on a 7700 realtime PCR system apparatus. PCR amplification using real-time PCR was performed as described above. A standard curve for each gene was generated by serial dilution of the amplified product standard of the known starting concentration. Glyceraldehyde-3phosphate dehydrogenase mRNA, which yielded an amplicon of $203 \mathrm{bp}$, was used as a control (primers 5'AAGAAGGTGGTGAAGCAGGC3' and 5'TCCACCACCCTGTTGCTGTA3') for data normalization. The PCR primers used for each gene in this analysis are given in table 3. Expression was assessed by evaluating CT values. The relative amount of expressed mRNA was calculated by the $2^{-\Delta \Delta C T}$ method [30]. The experiment was performed in triplicate.

\section{Methyl-DNA Immunoprecipitation- $q P C R$}

We prepared genomic DNA from 15 MCNS patients and 15 healthy controls by overnight proteinase $\mathrm{K}$ treatment, phenolchloroform extraction, ethanol precipitation and RNase digestion. Before carrying out methyl-DNA immunoprecipitation, we sonicated genomic DNA to produce random fragments ranging in size from 200 to $1,000 \mathrm{bp}$. We used $6 \mu \mathrm{g}$ of fragmented DNA for a standard methyl-DNA immunoprecipitation assay. Following denaturation $\left(95^{\circ} \mathrm{C} 10 \mathrm{~min}\right)$, the DNA was incubated overnight at $4^{\circ} \mathrm{C}$ with $8 \mu \mathrm{g}$ of 5 -methylcytidine monoclonal antibody (Eurogentec). $50 \mu \mathrm{l}$ of rabbit anti-IgG magnetic beads (S1430S; BioLabs) were added and incubated for $2 \mathrm{~h}$ at $4^{\circ} \mathrm{C}$. Magnetic beads-monoclonal antibody-DNA complexes were sequentially washed by gentle mixing at $4^{\circ} \mathrm{C}$ for $4 \mathrm{~min}$ with $1 \mathrm{ml}$ of wash buffer 1 (2 mM EDTA; 20 mM Tris, pH 8.0; 1\% Triton X-100; 0.1\% SDS; $150 \mathrm{~mm} \mathrm{NaCl}$ ), wash buffer 2 (2 mM EDTA; $20 \mathrm{~mm}$ Tris, $\mathrm{pH}=8.0$; $1 \%$ Triton X-100; $0.1 \%$ SDS; $500 \mathrm{mM} \mathrm{NaCl}$ ) and wash buffer 3 (1 mM EDTA; 10 mM Tris, $\mathrm{pH}=8.0$ ). After washing the complex-
Table 4. Primers used in methyl-DNA immunoprecipitationqPCR

\begin{tabular}{llll}
\hline Gene & Primer sequence $\left(5^{\prime}\right.$ to $\left.3^{\prime}\right)$ & $\begin{array}{l}\text { Anneal- } \\
\text { ing, }{ }^{\circ} \mathrm{C}\end{array}$ & $\begin{array}{l}\text { Size } \\
\text { bp }\end{array}$ \\
\hline IL4R & $\begin{array}{l}\text { F: AGTTCTGTCTAAATGCGTCCGT } \\
\text { R: GAACTCAATTCCACCAAACCCT }\end{array}$ & 59 & 290 \\
\hline HIVEP3 & $\begin{array}{l}\text { F: CAGCTCGCTATTCTGCTTCG } \\
\text { R: CACAGGACCAGTTTGCCATC }\end{array}$ & 59 & 139 \\
\hline PRKD2 & $\begin{array}{l}\text { F: GAGCTGCGAAGGAAGAGGA } \\
\text { R: GAGGCTGAGGCACGAGAAT }\end{array}$ & 59 & 277 \\
\hline HPSE2 & $\begin{array}{l}\text { F: GGAAAGCATTAGGCGAACAGG } \\
\text { R: GCTCGTCCGAATGTAGGGTG }\end{array}$ & 59 & 143 \\
\hline CDH13 & $\begin{array}{l}\text { F: GACATTGCCGTCTGTTTCCT } \\
\text { R: CCACAGTGCCCTCCTGTTTAG }\end{array}$ & 59 & 292 \\
& & & \\
\hline
\end{tabular}

$\mathrm{F}=$ Forward primer $\mathrm{R}=$ reverse primer.

es on a magnetic separation rack for $10 \mathrm{~min}$ at $4^{\circ} \mathrm{C}$, elution was performed with $400 \mu$ l elution buffer (50 mM Tris- $\mathrm{HCl}, \mathrm{pH} 8.0$; 10 mM EDTA, pH 8.0; 1\% SDS). The elution fraction was obtained by phenol-chloroform extraction and ethanol precipitation. The quantity of immunoprecipitated DNA was checked with a Nanodrop spectrophotometer (Agilent). PCR amplification using realtime PCR was performed as described above. Relative enrichment of DNA methylation for each gene was determined by the same method as described above. The PCR primers used for each gene in this analysis are shown in table 4 . The experiment was performed in triplicate.

Statistical Analysis

Quantitative data are shown as mean values \pm SD. Statistical analyses were performed using an independent samples $t$ test. $\mathrm{p}<0.05$ was regarded as statistically significant.

\section{Results}

\section{Monitoring and Data Analysis by CPG Island Array}

In ChIP, the sonicated effects were judged by agarose gel electrophoresis. The genomic DNA fragment was approximately 1,000 bp (fig. 1). To obtain a global overview of the $\mathrm{H} 3 \mathrm{~K} 4 \mathrm{me} 3$ profiles of the MCNS patients and healthy subjects, the ChIP-chip data were first corrected for background and normalized to remove systematic bias. Methylation profiles were then determined by the ratios between normalized Cy5 and Cy 3 intensities. Ratios were used as a cutoff for scoring positive loci for $\mathrm{H} 3 \mathrm{~K} 4 \mathrm{me} 3$. Hence, we selected the ratios $>2$ as $\mathrm{H} 3 \mathrm{~K} 4 \mathrm{me} 3$ targets and identified 1,015 and 389 targets, respective- 
Table 5. The 20 selected probes with H3K4me3 alterations between MCNS patients and healthy subjects, identified by ChIP-CpG microarray analysis

\begin{tabular}{|c|c|c|c|c|}
\hline Probe ID & Fold change & Within & Genome location & Description \\
\hline UHNhscpg0001545 & 13.04 & PRKD2 & chr19:51892513-51893119 & protein kinase D2 \\
\hline UHNhscpg0009117 & 6.17 & ZNF333 & chr19:14661327-14662364 & ZNF333 protein \\
\hline UHNhscpg0005260 & 4.91 & TCF3 & chr19:1602017-1602493 & transcription factor 3 \\
\hline UHNhscpg0007184 & 3.44 & CACNA1D & chr3:53684940-53685411 & calcium channel, voltage-dependent, L type \\
\hline UHNhscpg0001742 & 2.90 & DNMT2 & chr10:17282923-17283980 & DNA (cytosine-5)-methyltransferase 2 \\
\hline UHNhscpg0009360 & 2.43 & PTPN13 & chr4:87734788-87735329 & protein tyrosine phosphatase, nonreceptor type \\
\hline UHNhscpg0007787 & 2.21 & LY75 & chr2:160468871-160469279 & lymphocyte antigen 75 \\
\hline UHNhscpg0007177 & 2.17 & HIVEP3 & $\operatorname{chr} 1: 42156111-42156820$ & HIV type I enhancer \\
\hline UHNhscpg0008263 & 2.09 & IL4R & chr16:27237494-27237759 & interleukin- 4 receptor $\alpha$-chain isoform a \\
\hline UHNhscpg0011633 & 2.01 & HSPA2 & chr14:64076557-64076742 & heat shock $70 \mathrm{kDa}$ protein 2 \\
\hline UHNhscpg0000762 & 0.49 & SLC25A15 & chr13:40281435-40281946 & solute carrier family 25 \\
\hline UHNhscpg0008961 & 0.43 & KIR3DL2 & chr19:60055042-60055358 & NK receptor \\
\hline UHNhscpg0003995 & 0.42 & LRP1B & chr2:141707608-141707767 & low-density lipoprotein-related protein $1 \mathrm{~B}$ \\
\hline UHNhscpg0002047 & 0.41 & MRPL27 & $\operatorname{chr} 17: 45805214-45805905$ & mitochondrial ribosomal protein L27 isoform a \\
\hline UHNhscpg0001251 & 0.39 & PISD & chr22:30387570-30388248 & phosphatidylserine decarboxylase \\
\hline UHNhscpg0002631 & 0.35 & $\mathrm{CDH} 13$ & chr16:81837847-81838485 & cadherin 13 preproprotein \\
\hline UHNhscpg0009999 & 0.33 & CLNS1A & chr11:77026062-77026447 & chloride channel, nucleotide-sensitive protein $1 \mathrm{~A}$ \\
\hline UHNhscpg0005112 & 0.21 & KIAA0241 & chr7:32911549-32911779 & KIAA0241 protein \\
\hline UHNhscpg0006307 & 0.22 & HPSE2 & chr10:100983740-100984257 & heparanase 2 \\
\hline UHNhscpg0000148 & 0.15 & METT1OD & $\operatorname{chr} 17: 2361322-2361754$ & MGC3329 protein \\
\hline
\end{tabular}

ly, using CpG arrays. Next, we analyzed H3K4me3 candidate gene variations between MCNS patients and healthy subjects. Our aim was to identify genes that underwent $\mathrm{H} 3 \mathrm{~K} 4 \mathrm{me} 3$ changes in MCNS patients compared with healthy subjects. For this, we adopted 2 steps to analyze this data. First, genes that showed significant differences (the ratio $>2$ or $<0.5$ ) between MCNS and control groups were considered H3K4me3 candidates. Second, genes that showed significant methylation differences between MCNS and control groups, but were not identified as $\mathrm{H} 3 \mathrm{~K} 4 \mathrm{me} 3$ targets, were excluded in the target list. These stringent restrictions might have caused some false negatives (i.e. genes that underwent changes in methylation but were not identified by our analysis), but it reduced the possibility of introducing too many false positives.

\section{Comparison of H3K4me3 Status between MCNS \\ Patients and Healthy Subjects}

By applying the above analysis procedure to the $\mathrm{CpG}$ array, we found that 1,079 probes displayed significant H3K4me3 differences in MCNS patients compared with healthy subjects. Among these probes, 848 displayed increased H3K4me3, and 231 showed decreased H3K4me3. These identified genes included immunity, cell signal transduction, protein transcription and synthesis, ion channel and transporters, cell apoptosis, extracellular matrix, etc. The H3K4me3 alterations of the 20 selected genes are presented in table 5 .

\section{Validation for CpG Microarray Data}

To validate the microarray results, selected genes that displayed increased H3K4me3 (IL4R PRKD2) and decreased H3K4me3 (HPSE2 CDH13) in MCNS patients were then verified by ChIP-qPCR. As shown in table 6 , the qPCR results of these chosen $\mathrm{H} 3 \mathrm{~K} 4 \mathrm{me} 3$ candidates are consistent with the ChIP array analyses. Taken together, these ChIP validations support the accuracy of the array data.

\section{H3K4me3 Alterations and Gene Expression}

To confirm correlations between $\mathrm{H} 3 \mathrm{~K} 4 \mathrm{me} 3$ and gene expression, we performed mRNA expression analysis by real-time qRT-PCR for the 4 randomly selected H3K4me3 candidates (IL4R, HIVEP3, PRKD2 and HPSE2). As shown in table 7, there are mRNA expression changes of the H3K4me3 candidates in MCNS patients compared with healthy subjects. Our results further support the previous views that high levels of $\mathrm{H} 3 \mathrm{~K} 4 \mathrm{me} 3$ are associated with active genes. 
Table 6. Quantitative real-time PCR verification of ChIP-chip data

\begin{tabular}{lllll}
\hline Probe ID & Gene & $\begin{array}{l}\text { Quantitative } \\
\text { real-time, PCR }\end{array}$ & & $\begin{array}{l}\text { Micro- } \\
\text { array } \\
\text { change }\end{array}$ \\
\cline { 2 - 3 } & $\mathrm{M}$ & $\mathrm{C}$ & $\mathrm{M}$ \\
\hline UHNhscpg0008263 IL4R & 1.00 & $1.48 \pm 0.03^{*}$ & $\mathrm{U}$ \\
UHNhscpg0001545 PRKD2 & 1.00 & $2.66 \pm 0.02^{*}$ & $\mathrm{U}$ \\
UHNhscpg0006307 HPSE2 & 1.00 & $0.79 \pm 0.03^{*}$ & $\mathrm{D}$ \\
UHNhscpg0002631 CDH13 & 1.00 & $0.48 \pm 0.02^{*}$ & $\mathrm{D}$ \\
\hline
\end{tabular}

Microarray changes (H3K27me3) are presented as upregulated (U) or downregulated (D) compared to the healthy group. Similarly, real-time PCR values are expressed as the mean \pm SD compared to the healthy group. Quantitative data was calculated by $2^{-\Delta \Delta \mathrm{CT}}$. Assays were done in triplicate. ${ }^{*} \mathrm{p}<0.05$, which is considered to be statistically significant (independent samples t test).

$\mathrm{M}=$ MCNS group; $\mathrm{C}=$ healthy subjects group.

\section{Relationships between H3K4me3 and DNA \\ Methylation}

To study the mechanisms and the relationships between H3K4me3 and DNA methylation further, we examined the methylation status of the 5 selected positive genes, IL4R, HIVEP3, PRKD2, HPSE2 and CDH13 in MCNS patients compared with healthy subjects. The results are presented in table 8 .

\section{Discussion}

Modifications of histone tails are thought to specify a code that regulates the expression of genes [31]. The emerging consensus is that high levels of $\mathrm{H} 3 \mathrm{~K} 4 \mathrm{me} 3$ are associated with active genes. Analyses of H3K4me3 distribution indicate that this histone modification occurs primarily in the vicinity of the transcription start site [32, 33]. To cover these regions in this study, we used human $12 \mathrm{~K} \mathrm{CpG}$ island arrays, which contain a significant percentage of the $\mathrm{CpG}$ islands found in the human genome with approximately $68 \%$ located near a transcription start site, although not fully representative of promoter regions [34]. H3K4me3 was observed several years back, but its subtle inter-relationships with other epigenetic modifications and potential functional significance in human disease are still not very well known. At present, the consensus is that MCNS involves immune abnor-
Table 7. H3K4me3 variations and mRNA expression levels with real-time qRT-PCR analysis

\begin{tabular}{lllll}
\hline Probe ID & Gene & \multicolumn{2}{l}{ qRT-PCR } & $\begin{array}{l}\text { Micro- } \\
\text { array } \\
\text { change }\end{array}$ \\
\cline { 3 - 5 } & & & & $\mathrm{M}$ \\
\cline { 3 - 5 } & & $\mathrm{M}$ & $\mathrm{C}$ & $\mathrm{U}$ \\
\hline UHNhscpg0001545 & PRKD2 & 1.00 & $1.53 \pm 0.04^{*}$ & $\mathrm{U}$ \\
UHNhscpg0008263 & IL4R & 1.00 & $1.43 \pm 0.03^{*}$ & $\mathrm{U}$ \\
UHNhscpg0006882 & HIVEP3 & 1.00 & $1.75 \pm 0.02^{*}$ & $\mathrm{U}$ \\
UHNhscpg0006307 & HPSE2 & 1.00 & $0.78 \pm 0.03^{*}$ & $\mathrm{D}$ \\
UHNhscpg0002631 & CDH13 & 1.00 & $0.53 \pm 0.02^{*}$ & $\mathrm{D}$ \\
\hline
\end{tabular}

Microarray changes (H3K4me3) are presented as upregulated (U) or downregulated (D) compared to the healthy group. Similarly, relative mRNA values are expressed as the mean \pm SD compared to the healthy group. Quantitative data was calculated by $2^{-\Delta \Delta C T}$. The experiments were done in triplicate. ${ }^{*} p<0.05$, which is considered to be statistically significant (independent samples $t$ test).

$\mathrm{M}=$ MCNS group; $\mathrm{C}=$ healthy subject group.

malities in PBMCs including the B and T lymphocytes, monocytes and natural killer cells. Based on these, in this study, we selected $\mathrm{H} 3 \mathrm{~K} 4 \mathrm{me} 3$ as a target to be investigated by the ChIP-chip strategy and explored the hypothesis that $\mathrm{H} 3 \mathrm{~K} 4 \mathrm{me} 3$ is associated with the pathogenesis of MCNS.

In the present study, we mainly analyzed the trimethylation status of $\mathrm{H} 3 \mathrm{~K} 4$ in MCNS patients and healthy subjects. All in all, these genes included genes associated with immunity, cell signal transduction, protein transcription and synthesis, ion channel and transporters, cell apoptosis, DNA and RNA processing and extracellular matrix, etc. Using ChIP-qPCR, we were able to confirm the validity of the microarray data, and the consistency of the results ultimately proves the value of this approach.

Among the candidates identified in the $\mathrm{CpG}$ array, we found that IL4R, HIVEP3 and PRKD2 displayed increased H3K4me3. The IL4R gene encodes the $\alpha$-chain of the interleukin- 4 receptor, a type I transmembrane protein that can bind interleukin- 4 and interleukin- 13 to regulate IgE production [35]. The encoded protein also can bind interleukin- 4 to promote differentiation of Th2 cells [36]. A number of reports have shown that MCNS is frequently associated with atopy and elevation of serum IgE levels [5-8]. In this study, we observed that the mRNA expression of IL4R was upregulated, which is consistent with a previous study [37]. HIVEP3, also known as rec- 
Table 8. The relationship between $\mathrm{H} 3 \mathrm{~K} 27 \mathrm{me} 3$ alterations and DNA methylation levels by real-time PCR analysis

\begin{tabular}{lllll}
\hline Probe ID & Gene & \multicolumn{2}{l}{ MeDIP-qPCR } & $\begin{array}{l}\text { Micro- } \\
\text { array } \\
\text { change }\end{array}$ \\
\cline { 3 - 5 } & & $\mathrm{M}$ & $\mathrm{C}$ & $\mathrm{M}$ \\
\hline UHNhscpg0008263 & IL4R & 1.00 & $0.69 \pm 0.02^{*}$ & $\mathrm{U}$ \\
UHNhscpg0007177 & HIVEP3 & 1.00 & $0.62 \pm 0.05^{*}$ & $\mathrm{U}$ \\
UHNhscpg0009064 & MMP15 & 1.00 & $0.83 \pm 0.03^{*}$ & $\mathrm{U}$ \\
UHNhscpg0006307 & HPSE2 & 1.00 & $1.53 \pm 0.02^{*}$ & $\mathrm{D}$ \\
UHNhscpg0004607 & RB1 & 1.00 & $1.68 \pm 0.02^{*}$ & $\mathrm{D}$ \\
\hline
\end{tabular}

Microarray changes (H3K4me3) are presented as upregulated (U) or downregulated (D) compared to the healthy group. Similarly, real-time PCR values (DNA methylation levels) are expressed as the mean \pm SD compared to the healthy group. Quantitative data was calculated by $2^{-\Delta \Delta C T}$. The experiments were done in triplicate. ${ }^{*} \mathrm{p}<0.05$, which is considered to be statistically significant (independent samples t test).

MeDIP = Methyl-DNA immunoprecipitation; $\mathrm{M}=$ MCNS group; $\mathrm{C}=$ healthy subjects group.

ognition component (KRC), which is a large protein composed of 2,282 amino acids, is induced upon T cell receptor signaling in $\mathrm{T}$ cells and functions to regulate the expression of the interleukin-2 gene. Overexpression of $\mathrm{KRC}$ in transformed and primary $\mathrm{T}$ cells leads to increased interleukin-2 production, whereas dominant negative KRC, or loss of KRC protein in KRC-null mice, results in a diminished interleukin-2 production [38]. KRC plays a critical role in the NFKB and JNK pathways in regulating $\mathrm{CD} 4 \mathrm{~T}$ cell activation, effector function and cytokine gene expression as well as $\mathrm{T}$ cell survival and death $[39,40]$. PRKD2, a member of the protein kinase $\mathrm{D}$ family serine/threonine kinases, is expressed in a wide range of cells and regulates various cellular responses, including immune responses. PRKD2 is involved in interleukin-2 promoter regulation and cell death, depending on its activity upon TCR stimulation [41]. Recently, PRKD2 has also been reported to play a pivotal role in endothelial cell proliferation and migration necessary for angiogenesis at least in part through modulation of the expression of vascular endothelial growth factor receptor-2 and fibroblast growth factor receptor-1 [42]. In this study, we showed that the mRNA expression of IL4R, HIVEP3 and PRKD2 was upregulated. The H3K4 trimethylation of IL4R, HIVEP3 and PRKD2 will provide a new mechanism for activation of these genes and, therefore, immune abnormalities are involved in MCNS.
We also observed that the other 2 candidate genes, HPSE2 and CDH13, showed a significant decrease in histone $\mathrm{H} 3 \mathrm{~K} 4 \mathrm{me} 3$ in MCNS patients compared with healthy subjects. HPSE2 is a member of the heparanase family. Heparanase, an endo- $\beta$-D-glucuronidase, cleaves heparan sulfate at specific sites, leading to the release of growth factors that may be involved in decidualization and remodeling of the maternal vasculature. It is directly able to modulate the selective permeability of the glomerular capillary wall by its ability to degrade heparan sulfate glycosaminoglycan, which constitutes the charge barrier [43]. $\mathrm{CDH} 13$, a member of the cadherin superfamily, which is located at chromosome $16 \mathrm{q}$, is a cell-surface glycoprotein that is responsible for establishing and maintaining intercellular connections. The reduction of $\mathrm{H}$-cadherin expression has been reported in esophageal, breast and lung cancers [44-46]. In this study, our results showed that the mRNA expressions of HPSE2 and CDH13 were downregulated in MCNS patients compared with healthy subjects, and that these might engage in the pathogenesis of MCNS by mechanisms which are unclear at the present.

DNA methylation is a postsynthetic modification that is responsible for epigenetic modulation of gene expression. A large body of work has demonstrated that cytosine methylation of the regulatory sequences of DNA is associated with transcriptional inactivation of genes, while hypomethylation contributes to the activation of transcription $[47,48]$. DNA methylation and histone modification may act synergistically or antagonistically on gene expression [22,31]. Recent studies have suggested that acetylated histones and dimethylated histone $\mathrm{H} 3$ at lysine 4 (H3K4me2) are inversely correlated with DNA methylation $[49,50]$; however, it is less clear whether increased or decreased $\mathrm{H} 3 \mathrm{~K} 4 \mathrm{me} 3$ is also accompanied by local changes in DNA methylation in MCNS patients. Thus, we again selected 5 positive genes (IL4, HIVEP3, PRKD2, HPSE2 and $\mathrm{CDH} 13$ ) from this microarray to initially explore whether these modifications coincide in the context of this disease. We found that there is an inverse relationship between $\mathrm{H} 3 \mathrm{~K} 4 \mathrm{me} 3$ and promoter DNA methylation in MCNS patients. This may indicate that DNA methylation and $\mathrm{H} 3 \mathrm{~K} 4 \mathrm{me} 3$ are cooperatively involved in the pathogenesis of MCNS, at least in these genes.

We systematically evaluated the status of $\mathrm{H} 3 \mathrm{~K} 4 \mathrm{me} 3$ in PBMCs of MCNS patients, for the first time, and gained new insights into the links between $\mathrm{H} 3 \mathrm{~K} 4 \mathrm{me} 3$ and DNA methylation in the context of MCNS. Our results indicate that the alterations of $\mathrm{H} 3 \mathrm{~K} 4$ trimethylation are associated with the pathogenesis of MCNS and that these novel candidate genes may become potential biomarkers or future 
therapeutic targets. Further investigations are needed to clarify the roles of identified $\mathrm{H} 3 \mathrm{~K} 4 \mathrm{me} 3$ candidate genes in the pathogenesis of MCNS.

\section{Conclusion}

MCNS is thought to be a multifactorial disease, and the basic mechanisms behind MCNS are still waiting to be solved. Our results, however, suggest for the first time that $\mathrm{H} 3 \mathrm{~K} 4 \mathrm{me} 3$ alterations may play a role in MCNS. Expanding the epigenetic work to the other kidney diseases, therefore, seems called upon.

\section{Acknowledgements}

We are deeply grateful to all the volunteers who donated blood.

\section{References}

1 Minimal change nephrotic syndrome in children: deaths during the first 5 to 15 years' observation. Report of the International Study of Kidney Disease in Children. Pediatrics 1984;73:497-501.

2 Coggis $\mathrm{CH}$ : Minimal change nephrosis in adults; in Zurukzoglu W (ed): Treatable and Preventable Glomerular Disease, Proceedings of the 8th International Congress of Nephrology. Basel, Karger, 1981, pp 336-344.

3 Lewis EJ: Management of the nephrotic syndrome in adults; in Caeron JS, Glassock RJ (eds): The Nephrotic Syndrome. New York, Dekker, 1988, pp 461-521.

$\checkmark 4$ Cho MH, Hong EH, Lee TH, Ko CW: Pathophysiology of minimal change nephrotic syndrome and focal segmental glomerulosclerosis. Nephrology (Carlton) 2007; 12 (suppl 3):S11-S14.

5 van den Berg JG, Weening JJ: Role of the immune system in the pathogenesis of idiopathic nephrotic syndrome. Clin Sci (Lond) 2004;107:125-136.

6 Laflam PF, Garin EH: Effect of tumor necrosis factor alpha and vascular permeability growth factor on albuminuria in rats. Pediatr Nephrol 2006;21:177-181.

7 Koyama A, Fujisaki M, Kobayashi M, Igarashi $M$, Narita $M$ : A glomerular permeability factor produced by human $\mathrm{T}$ cell hybridomas. Kidney Int 1991;40:453-460.

$\checkmark 8$ Tanaka R, Yoshikawa N, Nakamura H, Ito H: Infusion of peripheral blood mononuclear cell products from nephrotic children increases albuminuria in rats. Nephron 1992; 60:35-41.

-9 Araya CE, Wasserfall $\mathrm{CH}$, Brusko TM, $\mathrm{Mu}$ W, Segal MS, Johnson RJ, Garin EH: A case of unfulfilled expectations: cytokines in idiopathic minimal lesion nephrotic syndrome. Pediatr Nephrol 2006;21:603-610.

10 Laflam PF, Haraguchi S, Garin EH: Cytokine mRNA profile in lipoid nephrosis: evidence for increased IL-8 mRNA stability. Nephron 2002;91:620-626.
11 Neuhaus TJ, Wadhwa M, Callard R, Barratt TM: Increased IL-2, IL-4 and interferongamma (IFN-gamma) in steroid-sensitive nephrotic syndrome. Clin Exp Immunol 1995;100:475-479.

12 Lachner M., Jenuwein T: The many faces of histone lysine methylation. Curr Opin Cell Biol 2002;14:286-298.

13 Martin C, Zhang Y: The diverse functions of histone lysine methylation. Nat Rev Mol Cell Biol 2005;6:838-849.

14 Ruthenburg AJ, Allis CD, Wysocka J: Methylation of lysine 4 on histone $\mathrm{H} 3$ : intricacy of writing and reading a single epigenetic mark. Mol Cell 2007;25:15-30.

15 Santos-Rosa H, Schneider R, Bannister AJ, Sherriff J, Bernstein BE, Emre NC, Schreiber SL, Mellor J, Kouzarides T: Active genes are tri-methylated at $\mathrm{K} 4$ of histone $\mathrm{H} 3$. Nature 2002;419:407-411.

16 Schneider R, Bannister AJ, Myers FA, Thorne AW, Crane-Robinson C, Kouzarides T: Histone $\mathrm{H} 3$ lysine 4 methylation patterns in higher eukaryotic genes. Nature Cell Biol 2004;6:73-77.

17 Bernstein BE, Kamal M, Lindblad-Toh K, Bekiranov S, Bailey DK, Huebert DJ, McMahon S, Karlsson EK, Kulbokas EJ 3rd, Gingeras TR, Schreiber SL, Lander ES: Genomic maps and comparative analysis of histone modifications in human and mouse. Cell 2005;120:169-181.

18 Bannister AJ, Kouzarides T: Histone methylation: recognizing the methyl mark. Methods Enzymol 2004;376:269-288.

-19 Fraga MF, Ballestar E, Villar-Garea A, et al: Loss of acetylation at Lys16 and trimethylation at Lys 20 of histone $\mathrm{H} 4$ is a common hallmark of human cancer. Nat Genet 2005; 37:391-400.

20 Wu J, Smith LT, Plass C, Huang TH: ChIPchip comes of age for genome-wide functional analysis. Cancer Res 2006;66:6899-6902.

$>21$ Wu J, Wang SH, Potter D, Liu JC, Smith LT, Wu YZ, Huang TH, Plass C: Diverse histone modifications on histone 3 lysine 9 and their relation to DNA methylation in specifying gene silencing. BMC Genomics 2007;8:131.
22 O'Geen H, Squazzo SL, Iyengar S, Blahnik K, Rinn JL, Chang HY, Green R, Farnham PJ: Genome-wide analysis of KAP1 binding suggests autoregulation of KRAB-ZNFs. PLoS Genet 2007;3:e89.

23 Opel M, Lando D, Bonilla C, Trewick SC, Boukaba A, Walfridsson J, Trewick SC, Cauwood J, Werler PJ, Carr AM, Kouzarides T, Murzina NV, Allshire RC, Ekwall K, Laue ED: Genome-wide studies of histone demethylation catalysed by the fission yeast homologues of mammalian LSD1. PLoS ONE 2007;2:e386.

$>24$ Ren B, Robert F, Wyrick JJ, Aparicio O, Jennings EG, Simon I, Zeitlinger J, Schreiber J, Hannett N, Kanin E, Volkert TL, Wilson CJ, Bell SP, Young RA: Genome-wide location and function of DNA binding proteins. Science 2000;290:2306-2309.

$>25$ Weinmann AS, Yan PS, Oberley MJ, Huang TH, Farnham PJ: Isolating human transcription factor targets coupling chromatin immunoprecipitation and $\mathrm{CpG}$ island microarray analysis. Genes Dev 2002;16:235-244.

26 Miao F, Wu X, Zhang L, Yuan YC, Riggs AD, Natarajan R: Genome-wide analysis of histone lysine methylation variations caused by diabetic conditions in human monocytes. J Biol Chem 2007;282:13854-13863.

27 Zhang L, Zhong K, Dai Y, Zhou H: Genomewide analysis of histone $\mathrm{H} 3$ lysine 27 trimethylation by ChIP-chip in gastric cancer patients. J Gastroenterol 2009;44:305-312.

$\checkmark 28$ Kondo Y, Shen L, Cheng AS, Ahmed S, Boumber Y, Charo C, Yamochi T, Urano T, Furukawa K, Kwabi-Addo B, Gold DL, Sekido Y, Huang TH, Issa JP: Gene silencing in cancer by histone $\mathrm{H} 3$ lysine 27 trimethylation independent of promoter DNA methylation. Nat Genet 2008;40:741-750.

29 Huebert DJ, Kamal M, O’Donovan A, Bernstein BE: Genome-wide analysis of histone modifications by ChIP-on-chip. Methods 2006;40:365-369

30 Livak KJ, Schmittgen TD: Analysis of relative gene expression data using real-time quantitative PCR and the 2(-Delta Delta C(T)) method. Methods 2001;25:402-408. 
-31 Jenuwein T, Allis CD: Translating the histone code. Science 2001;293:1074-1080.

-32 Roh TY, Cuddapah S, Cui K, Zhao K: The genomic landscape of histone modifications in human T cells. Proc Natl Acad Sci USA 2006;103:15782-15787.

>33 Liang G, Lin JC, Wei V, Yoo C, Cheng JC, Nguyen CT, Weisenberger DJ, Egger G, Takai D, Gonzales FA, Jones PA: Distinct localization of histone $\mathrm{H} 3$ acetylation and $\mathrm{H} 3-\mathrm{K} 4$ methylation to the transcription start sites in the human genome. Proc Natl Acad Sci USA 2004;101:7357-7362.

-34 Heisler LE, Torti D, Boutros PC, Watson J, Chan C, Winegarden N, Takahashi M, Yau P, Huang TH, Farnham PJ, Jurisica I, Woodgett JR, Bremner R, Penn LZ, Der SD: CpG island microarray probe sequences derived from a physical library are representative of $\mathrm{CpG}$ islands annotated on the human genome. Nucleic Acids Res 2005;33:2952-2961.

-35 Izuhara K: Atopy and interleukin-4 receptor (in Japanese). Rinsho Byori 1999;47:525530.

-36 Andrews AL, Holloway JW, Holgate ST, Davies DE: IL-4 receptor alpha is an important modulator of IL-4 and IL-13 receptor binding: implications for the development of therapeutic targets. J Immunol 2006;176: 7456-7461.
-37 Lai KW, Wei CL, Tan LK, Tan PH, Chiang GS, Lee CG, Jordan SC, Yap HK: Overexpression of interleukin-13 induces minimalchange-like nephropathy in rats. J Am Soc Nephrol 2007; 18:1476-1485.

38 Oukka M, Wein MN, Glimcher LH. Schnurri-3 (KRC) interacts with c-Jun to regulate the IL-2 gene in T cells. J Exp Med 2004;199: 15-24.

39 Leppä S, Bohmann D: Diverse functions of JNK signaling and c-Jun in stress response and apoptosis. Oncogene 1999;18:61586162.

40 Ghosh S, May MJ, Kopp EB: NF-kappaB and Rel proteins: evolutionarily conserved mediators of immune responses. Annu Rev Immunol 1998;16:226-260.

-41 Irie A, Harada K, Tsukamoto H, Kim JR, Araki N, Nishimura Y: Protein kinase D2 contributes to either IL-2 promoter regulation or induction of cell death upon TCR stimulation depending on its activity in Jurkat cells. Int Immunol 2006;18:1737-1747.

42 Hao Q, Wang L, Zhao ZJ, Tang H: Identification of protein kinase $\mathrm{D} 2$ as a pivotal regulator of endothelial cell proliferation, migration, and angiogenesis. J Biol Chem 2009; 284:799-806.

43 D’Souza SS, Fazleabas AT, Banerjee P, Sherwin JR, Sharkey AM, Farach-Carson MC Carson DD: Decidual heparanase activity is increased during pregnancy in the baboon (Papio anubis) and in in vitro decidualization of human stromal cells. Biol Reprod 2008;78:316-323.
-44 Jin Z, Cheng Y, Olaru A, Kan T, Yang J, Paun B, Ito T, Hamilton JP, David S, Agarwal R, Selaru FM, Sato F, Abraham JM, Beer DG, Mori Y, Shimada Y, Meltzer SJ: Promoter hypermethylation of CDH13 is a common, early event in human esophageal adenocarcinogenesis and correlates with clinical risk factors. Int J Cancer 2008;123:2331-2336.

$\checkmark 45$ Toyooka KO, Toyooka S, Virmani AK, Sathyanarayana UG, Euhus DM, Gilcrease M, Minna JD, Gazdar AF: Loss of expression and aberrant methylation of the $\mathrm{CDH} 13$ (Hcadherin) gene in breast and lung carcinomas. Cancer Res 2001;61:4556-4560.

-46 Kim DS, Kim MJ, Lee JY, Kim YZ, Kim EJ, Park JY: Aberrant methylation of E-cadherin and $\mathrm{H}$-cadherin genes in nonsmall cell lung cancer and its relation to clinicopathologic features. Cancer 2007;110:2785-2792.

47 Delcuve GP, Rastegar M, Davie JR: Epigenetic control. J Cell Physiol 2009;219:243250.

48 Law JA, Jacobsen SE: Molecular biology: dynamic DNA methylation. Science 2009;323: 1568-1569.

49 Irvine RA, Lin IG, Hsieh CL: DNA methylation has a local effect on transcription and histone acetylation. Mol Cell Biol 2002;22: 6689-6696.

50 Okitsu CY, Hsieh CL: DNA methylation dictates histone H3K4 methylation. Mol Cell Biol 2007;27:2746-2757. 